\title{
PERBANDINGAN KONSEP TUJUAN PENDIDIKAN IKHWAN AL-SAFA DENGAN PENDIDIKAN ISLAM DI INDONESIA MASA PERGERAKAN
}

\author{
Zahira Irhamni Arrovia \\ Universitas Negeri Malang \\ zahiraibrar@gmail.com \\ Yuliati \\ Universitas Negeri Malang \\ yuliati.fis@um.ac.id
}

\begin{abstract}
Abstrak
Ikhwan Al-Safa merupakan organisasi yang menekuni bidang kajian filsafat pendidikan, khususnya dalam pendidikan Islam. Adapun salah satu hasil pemikirannya terhadap tujuan pendidikan adalah moral dan dilandaskan pada aliran filsafat religius-rasional. Pendidikan Islam tidak hanya berkembang di wilayah yang berbasis agama Islam, melainkan juga terdapat di beberapa negara seperti Indonesia. Pendidikan Islam di Indonesia mulai mengalami pembaruan pada masa pergerakan atau abad ke-20 Masehi. Banyak organisasi Islam yang memberikan perhatiannya terhadap kondisi pendidikan Islam di Indonesia, seperti Adabiyah school, Muhammadiyah, Nahdlatul Ulama, dan sebagainya. Berdasarkan pemaparan tersebut maka penulisan dalam artikel ini hendak mengkaji perbandingan dari tujuan pendidikan berdasarkan pemikiran Ikhwan Al Safa dengan tujuan pendidikan di Indonesia pada masa pergerakan nasional. Metode penelitian menggunakan jenis kualitatif deskriptif, sumber data berupa sumber tertulis relevan, dan teknik analisis data yang digunakan content analysis. Berdasarkan hasil yang diperoleh antara tujuan pendidikan Islam Ikhwan Al Safa dengan pendidikan Islam di Indonesia masa pergerakan memiliki persamaan yaitu mencetak generasi yang berlandaskan pada ajaran Islam dan berintelektual. Namun, antara keduanya tentunya memiliki perbedaan dimana organisasi Islam di Indonesia dalam merumuskan tujuan pendidikannya tergantung dari aliran filsafat yang mereka tekuni.
\end{abstract}

Kata Kunci: Ikhwan Al Safa, Pendidikan Islam, Pergerakan Nasional

\begin{abstract}
Ikhwan Al Safa is an organization that is engaged in the study of educational philosophy, especially in Islamic education. One of the results of his thoughts on the purpose of education is moral and it is based on a religious-rational philosophy. Islamic education is not only developing in areas based on Islam, but also in several countries such as Indonesia. Islamic education in Indonesia began to experience renewal during the movement or the 20th century AD. Many Islamic organizations pay attention to the condition of Islamic education in Indonesia, such as the Adabiyah school, Muhammadiyah, Nahdlatul Ulama, and so on. Based on this explanation, the
\end{abstract}




\section{AL- ADABIYAH: Jurnal Pendidikan Agama Islam}

writing in this article intends to examine the comparison of educational goals based on the thoughts of Ikhwan Al Safa with the goals of education in Indonesia during the national movement. The research method uses descriptive qualitative type, the data source is the form of relevant written sources, and the data analysis technique used is content analysis. Based on the results obtained, the objectives of Ikhwan Al Safa's Islamic education and Islamic education in Indonesia during the movement have the same thing, namely creating a generation that is based on Islamic teachings and intellectuals. However, there are differences between the two of course, where Islamic organizations in Indonesia in formulating their educational goals depend on the philosophical stream which they are engaged in.

Keywords: Ikhwan Al Safa, Islamic Education, National Movement

\section{Pendahuluan}

Ilmu pengetahuan secara terus-menerus mengalami perkembangan, dan untuk merealisasikannya ditempuh melalui jalur pendidikan. Pendidikan dapat dikatakan sebagai usaha sadar setiap individu yang dilakukan secara terstruktur dalam rangka untuk memperoleh ilmu pengetahuan. Menurut Piaget (1896) dalam Sagala (2013:38) bahwa pendidikan merupakan jembatan yang menghubungkan dua sisi, yaitu sisi pertama adalah siswa yang tengah berada dalam proses belajar, sedangkan sisi lainnya yaitu guru yang bertanggung jawab dalam menyampaikan dan memberikan nilai moral, sosial, serta pengetahuan kepada siswa. Melalui pendidikan diharapkan dapat membentuk dan mencetak setiap individu agar menjadi manusia beradab dan berintelektual, sehingga dapat menyesuaikan diri dan mampu menghadapi tantangan di masa yang akan datang. Selain itu, pendidikan juga termasuk dalam kajian ilmu filsafat, karena setiap ruang lingkup dalam pendidikan berpedoman pada landasan filosofis.

Secara terminologi, menurut Aristoteles (384-322 SM) bahwa filsafat merupakan hakikat dari ilmu pengetahuan yang membahas tentang pengetahuan praktis, retorika, metafisika, logika, dan fisika (Lubis, 2015:7; Ibda, 2018:3). Selanjutnya dijelaskan oleh Al-Farabi bahwa filsafat didefinisikan sebagai al-ilm bi al-mawjid bima huwa maujud yaitu ilmu yang mengkaji tentang berbagai hal yang ada untuk dianalisis hakikat kebenarannya (Nasution, 2016:28). Berdasarkan pemaparan tersebut, maka filsafat dapat dikatakan sebagai bidang studi yang ditujukan untuk mengkaji secara mendalam dan kritis terhadap berbagai peristiwa atau fenomena dalam kehidupan. Bagi seseorang yang mendalami makna filosofis terhadap suatu peristiwa atau objek dari filsafat, hendaknya dapat meninggalkan kesibukan dalam dunianya sehingga dapat melakukan proses berpikir secara jernih. Kondisi tersebut dapat mendukung seseorang dalam berpikir secara filsafat 


\section{AL- ADABIYAH: Jurnal Pendidikan Agama Islam}

untuk memecahkan suatu permasalahan yang dijadikan sebagai objek kajian filsafat (Ritaudin, 2015). Adapun cabang dari filsafat meliputi ontologi, episteminilogi, dan aksiologi.

Filsafat pendidikan merupakan salah satu bidang filsafat yang menjadikan pendidikan sebagai objek kajiannya. Cabang dalam filsafat memiliki korelasi dengan kajian filsafat pendidikan, sehingga dapat digunakan dalam melakukan perencanaan dan pengembangan dalam pendidikan, serta dapat memberikan solusi dalam memecahkan masalah yang terjadi dalam dunian pendidikan. Menurut Soeprapto (2013) menjelaskan maksud dari ketiga cabang filsafat dalam pendidikan yaitu pertama ontologi pendidikan membahas tentang hakikat dari pendidikan dan hubungannya dengan hakikat keberadaan manusia, kedua episteminologi pendidikan mengkaji hakikat dari suatu kebenaran dan hubungannya dengan berbagai teori dalam pendidikan, dan ketiga aksiologi pendidikan membahas tentang implementasi dari berbagai teori pendidikan dan korelasinya dengan tujuan pendidikan.

Pendidikan yang ditinjau berdasarkan filsafat digunakan sebagai pedoman dalam memberikan arahan untuk mencapai tujuan pendidikan yang dianut oleh setiap individu, kelompok, bahkan pada tingkat negara. Maka dari itu, filsafat yang dianut oleh setiap tingkat dalam suatu birokrasi negara memberikan pengaruh terhadap tujuan pendidikan yang hendak dicapai. Selain itu, negara yang menganut terhadap filsafat tertentu memberikan dampak terhadap kegiatan pendidikan dan tujuan pendidikan diselaraskan dengan konsep falsafah atau ideologi negara tersebut. Pada dasarnya tujuan dalam pendidikan merupakan suatu rancangan yang bersifat komprehensif tentang hal-hal yang hendaknya ingin dicapai (Kristiawan, 2016:10). Tujuan yang telah dirumuskan berisikan tentang penjelasan terkait dengan kapabilitas yang ingin dicapai dan dapat dimiliki oleh setiap siswa, sehingga dapat disesuaikan dengan ideologi (falsafah) yang berlaku pada suatu negara.

Filsafat merupakan hasil dari pemikiran kritis oleh seorang filsuf, yang nantinya dijadikan sebagai sebuah pedoman, begitu pula dalam filsafat pendidikan. Terdapat banyak pemikir yang menaruh perhatiannya terhadap pendidikan, salah satunya adalah Ikhwan Al-Safa. Ikhwan Al-Safa merupakan sebuah organisasi yang bersifat rahasia yang mengutamakan pada aspek pendidikan dan pengajarannya memiliki korelasi dalam pembentukan pribadi, jiwa, serta akidah (Nata, 2005:231; Hidayatullah, 2013). Organisasi ini diperkirakan 


\section{AL- ADABIYAH: Jurnal Pendidikan Agama Islam}

berasal dari kota Basrah (Irak) dan berkembang pada akhir abad kedua Hijriyah. Selain itu, sumber lain pula mengatakan bahwa Ihwan Al-Safa berdiri sekitar abad ke-4 Hijriah atau jika didasarkan pada Masehi berdiri pada abad ke-10 (Sirajuddin Zar, 2004:139; Rajab, 2016). Sebagai organisasi dalam pendidikan yang didasarkan pada kajian filsafat tentunya membahas berbagai kajian filosofis pendidikan seperti mengkaji tentang ranah dalam ruang lingkup pendidikan.

Ikhwan Al-Safa sebagai organisasi rahasia yang memprioritaskan pada kajian bidang pendidikan lebih berbasis pada agama, khususnya agama Islam. Di Indonesia pendidikan Islam diperkirakan telah ada sejak agama Islam tumbuh dan berkembang dibeberapa wilayah. Terdapat banyak hipotesis terkait masuknya agama Islam di Indonesia, namun berdasarkan hasil dari seminar yang membahas masuknya agama Islam di Indonesia di Medan memutuskan bahwa agama Islam pertama kali hadir di Indonesia pada abad ke-7 Masehi atau 1 Hijriah yang dibawa oleh pedagang dari Arab (Nursyarief, 2014). Akan tetapi, hadirnya Agama Islam pertama kali pada abad ke-7 Masehi belum adanya informasi terkait kondisi awal pendidikan Islam di Indonesia. Selanjutnya berdasarkan tahapan waktunya, pendidikan Islam di Indonesia dibagi menjadi tujuh yaitu, pertama tahap awal Islam hadir di Indonesia, kedua proses penyesuaian Agama Islam terhadap masyarakat Indonesia ketika itu, ketiga berdirinya kesultanan Islam di Indonesia, keempat pada masa kolonialisme penjajajah barat, kelima masa pendudukan Jepang, keenam zaman kemerdekaan, dan ketujuh adalah tahap pembangunan (Zuhairini, 2000:7; Nursyarief, 2014).

Walaupun rentan masa antara berkembangnya Ikhwan Al-Safa dengan pendidikan Islam Indonesia berbeda, namun memiliki dasar yang sama yaitu disandarkan pada agama Islam. Maka dari itu dalam penulisan ini penulis ingin mengkaji konsep tujuan pendidikan Islam antara Ikhwan Al-Safa dengan pendidikan Islam di Indonesia pada masa pergerakan nasional yang diperkirakan berlangsung pada abad ke-20. Berdasarkan pemaparan sebelumnya, penulis mengemasnya dalam sebuah artikel dengan judul "Perbandingan Konsep Pemikiran Tujuan Pendidikan Ikhwan Al Safa dengan Pendidikan Islam di Indonesia Masa Pergerakan". Tujuan dari penulisan ini diantaranya, pertama membahas sejarah dari organisasi Ikhwan Al Safa; kedua pendidikan menurut pandangan Ikhwan Al Safa; ketiga pendidikan Islam di Indonesia pada masa pergerakan nasional, dan; keempat perbandingan tujuan pendidikan Ikhwan Al Safa dengan pendidikan Islam di Indonesia masa pergerakan. 


\section{AL- ADABIYAH: Jurnal Pendidikan Agama Islam}

\section{Tinjauan Literatur}

Pada tinjauan penelitian sebelumnya yang relevan pada penulisan ini yaitu berjudul "Konsep Pendidikan Ikhwan Al Safa dan Relevansinya dengan Dunia Postmodern" oleh Rahmad Afandi dari IAIN Purwokerto. Artikel tersebut memuat tentang organisasi rahasia yang dikenal dengan nama Ikhwan Al Safa, dimana organisasi tersebut juga mengemukakan pemikiran, gagasan, dan perhatiannya dalam dunia pendidikan. Ikhwan Al Safa didirikan di Bashrah dan diprediksikan pada tahun 340 H/951 M oleh Zayd Ibn Rifa'ah. Karya mereka yang terkenal yaitu Rasail Ihkwan Al Safa yang terdiri atas 52 risalah. Sebagai organisasi yang memberikan perhatiannya pada pendidikan, maka Ikhwan Al Safa juga memperhatikan ruang lingkup pendidikan diantaranya tujuan pendidikan, kurikulum pendidikan pada tingkat akademis, metode pembelajaran, dan sebagainya. Selanjutnya dalam penulisan artikel oleh Rahmad Afandi mengkaji dari konsep pendidikan yang dikemukakan oleh Ikhwan Al Safa, kemudian relevansinya dalam dunia Postmodern pada masa kini. Hasil dari pembahasan artikel tersebut adalah segala gagasan pemikiran Ikhwan Al Safa dalam pendidikan masih memiliki peranan penting dalam relevansinya terhadap pendidikan postmodern, baik berupa langkah-langkah untuk memperoleh ilmu pengetahuan, kompetensi guru, tujuan, kurikulum, bahkan metode yang diterapkan. Perbedaannya dengan penulisan artikel ini yang diangkat oleh penulis adalah hanya menekankan pada tujuan pendidikan berdasarkan pemikiran Ikhwan Al Safa lalu membandingkannya dengan pendidikan Islam ketika Indonesia memasuki masa pergerakan nasional.

Artikel selanjutnya yaitu dengan judul "Konsep Pendidikan Islam Ikhwan Al Safa, Suatu Kajian Analisis Kritis" oleh La Rajab. Pembahasan dalam artikel tersebut sama dengan artikel yang telah ditulis oleh Rahmad Efendi, namun perbedaannya adalah isinya yang melakukan analasis kritis terhadap konsep pemikiran pendidikan Ikhwan Al Safa. Adapun hasil dari analisis kritis tersebut bahwa konsep pendidikan berdasarkan pemikiran Ikhwan Al Safa lebih mengarah kepada spiritualitas dan secara keseluruhan pemberian atau pembekalan pendidikan harus diorientasikan pada fase remaja, karena remaja digolongkan dalam usia yang rawan jika tidak diatasi mulai saat ini menimbulkan pengaruh buruk. Dengan demikian, jika remaja telah diberikan pembekalan dan diberikan penanganan yang baik, maka akan melahirkan para generasi penerus yang tangguh dan baik. Adapun perbedaan artikel oleh La Rajab dengan penulisan ini, 


\section{AL- ADABIYAH: Jurnal Pendidikan Agama Islam}

yaitu tetap sama seperti sebelumnya, dimana penulisan artikel ini lebih menekankan pada tujuan pendidikan yang digagaskan oleh Ikwan Al Safa dan membandingkannya dengan tujuan pendidikan Islam masa pergerakan nasional.

\section{Metode}

Metode dalam penulisan ini menggunakan jenis penelitian kualitatif deskriptif dengan analisis atau interpretasi yang menitikberatkan pada pendekatan induktif. Teknik pengumpulan data berupa dokumentasi yang diambil melalui sumber tertulis relevan diantaranya, buku, jurnal, dan artikel. Setelah data-data diperoleh, tahap selanjutnya melakukan teknik analisis data untuk menafsirkan sumbersumber yang diperoleh dan kemudian menyajikan hasilnya dalam bentuk artikel. Adapun teknik analisis data yang digunakan adalah analysis content.

\section{Hasil dan Diskusi}

\section{A. Sejarah Ikhwan Al Safa}

Ikhwan Al Safa (Persaudaraan Kemurnian) merupakan sebuah organisasi yang bersifat rahasia dan para anggotanya terdiri atas para filsuf Muslim. Pusat pergerakan Ikhwan Al Safa berada di Basrah (Irak) dan diperkirakan berdiri pada tahun 373 Hijriah/983 Masehi, Secara komprehensif nama dari Ikhwan Al Safa yaitu Ikhwan Al-Safa wa Khullan al-Wafa wa Ahl al-Hamid wa Abna al-Majd (Sodik dan Zainol, 2018). Nama tersebut digagaskan pada mereka sebagaimana tercantum pada bab Merpati Berkalung dan Kalilah wa Dzimmah, yaitu buku yang dinilai sangat terpandang oleh mereka. Ikhwan Al-Safa melakukan kegiatanya secara rahasia diperkirakan karena adanya pengaruh dari paham taqiyah dimana kehidupan masyarakat ketika itu didominasi oleh kaum Sunni. Selain itu, faktor lainnya adalah adanya kekhawatiran terhadap penguasa ketika itu yang menentang pemikiran baru dan melakukan penindasan terhadapnya, sehingga mengakibatkan anggota dari Ikhwan Al Safa jumlahnya terbatas. Pemilihan anggota yang hendak bergabung dalam Ikhwan Al Safa dipilih secara selektif berdasarkan beberapa kriteria yaitu pertama memiliki ilmu pengetahuan yang luas, kedua rasa loyal yang tinggi, ketiga komitmen, dan keempat berakhlak baik (Ramayulis, 1005:101-102; Hidayatullah, 2013). Adapun hal lainnya yang metararbelakangi munculnya Ikhwan Al Safa yaitu kondisi dalam penyelenggaraan pendidikan Islam yang sangat memprihatikan dan masuknya pengaruh ajaran dari luar Islam, sehingga mendorong semangat mereka untuk menggalakkan rasa cinta 


\section{AL- ADABIYAH: Jurnal Pendidikan Agama Islam}

kembali terhadap ilmu pengetahuan dalam golongan masyarakat Islam. Berdasarkan kondisi tersebut, maka ranah pergerakan filsafat oleh Ikhwan Al Safa lebih kepada pendidikan dengan mengutamakannya pada aspek pembentukan pada diri manusia, jiwa, serta akidah. Namun, ada beberapa yang menganggap bahwa Ikhwan Al Safa memiliki karakteristik pergerakannya pada arah kebatinan. Karya Ikhwan Al Safa yang terkenal yaitu Rasail Ikhwan Al Safa dimana terdiri dari 52 risalah yang pada bagian akhir dilengkapi oleh sebuah ikhtisar. Kumpulan dalam risalah tersebut memberikan sebuah gambaran terhadap filsafat Islam yang telah berada pada masa kejayaannya dan mencakup berbagai ilmu pengetahuan yang berkembang pada masanya. Selain itu, terdorongnya para anggota dari Ikhwan Al Safa menyusun Rasail Ikhwan Al Safa disinyalir sebagai respon ketidakpuasannya terhadap penyelenggaraan pendidikan dan kehidupan masyarakat Islam pada masanya. Maka dari itu, menurut Nizar (2002) dalam Afandi (2019) bahwa perencanaan terhadap rekonstruksi Ikhwan Al Safa diorientasikan pada dua prospek yaitu pertama memberikan pemahaman mengenai gagasan dari ketersediaan sumber yang ada atas segala sesuatu, dan bermanfaat untuk menentukan makna dari keseluruhan pengetahuan yang diperoleh, dan; kedua memetakan manfaat terhadap seluruh ilmu pengetahuan, baik untuk kepentingan pribadi, lingkungan, dan alam semesta sehingga setiap manusia dapat memiliki peluang untuk melakukan suatu tindakan yang didasarkan pada pengetahuan yang diperoleh untuk mencapai kebahagiaan dunia dan akhirat.

Rasail Ikhwan Al Safa memiliki beberapa keistimewaan yaitu pertama risalah tersebut terdiri atas kumpulan berbagai filsafat yang lazimnya dapat ditemukan dalam kitab-kitab filsafat; kedua terdapat daftar isi secara panjang dan detail, sehingga memudahkan para pembaca untuk mempelajari sesuatu yang diperlukan, dan; ketiga gaya penulisan dan pelafalan dalam risalah disuguhkan dengan sederhana dan mudah, sehingga bagi seseorang yang baru mempelajari filsafat dengan mudah dapat memahaminya. Mengenai hal tersebut, Rasail Ihkwan Al Safa merupakan upaya pertama yang dilakukan oleh Ikhwan Al Safa dalam menyatukan antara ilmu pengetahuan dan agama. Menurut Nakosteen (2003:136) dalam Hidayatulloh (2014) bahwa pada BAB XIV membahas filologi dan psikologis, sehingga bagi mahasiswa pendidikan dan psikologi sangat penting untuk dijadikan rujukan dalam bidang studinya. 


\section{AL- ADABIYAH: Jurnal Pendidikan Agama Islam}

\section{B. Pendidikan Menurut Pemikiran Ikhwan Al Safa}

Berdasarkan berbagai jenis aliran pendidikan terutama dalam Islam, dibagi menjadi tiga yaitu konservatif, religius-rasional, dan pragmatis instrumental. Ikhwan Al Safa sebagai organisasi filsafat yang bergerak dalam pendidikan menganut aliran religius-rasional. Aliran religius-rasional menyatakan bahwa segala ilmu dan sastra yang tidak mampu mengantarkan manusia terhadap kehidupan akhirat dan tidak memberikan suatu makna untuk dijadikan bekal disana, maka ilmu tersebut hanya berperan sebagai boomerang bagi manusia tersebut (Kurniawan, 2019). Dalam lingkup pendidikan Islam, menurut aliran religius-rasional bahwa pendidikan tidak hanya berpacu pada sesuatu yang kajiannya bersifat rasional-empirik, melainkan proses pendidikan juga menghadirkan segala hal yang bersifat transedental. Berdasarkan pernyataan tersebut dapat diartikan sebagai adanya sebuah sinkronisasi antara sudut pandang yang bersifat rasional-objektif dengan pemahaman transendetal yang diwujudkan dalam pendidikan Islam yaitu akhirat dan duniawi, baik dalam segi ontologi, episteminologi, maupun aksiologi.

Menurut pandangan Ikhwan Al Safa setiap anak yang dilahirkan diibaratkan dengan tabularasa, yang selanjutnya melakukan kontak hubungan dengan keluarga dan gurunya disekolah, sehingga mereka mendapatkan, ilmu, pengetahuan, dan proses dalam kehidupan yang tempuh dengan taklid, pengajaran, serta pemanfaatan akal (Tim Riset Majelis Tinggi Urusan Islam Mesir, 2015:1063). Selain itu, menurut Sodik dan Zainol (2018) bahwa setiap akal dan emosi pada setiap anak dapat berkembang yang diawali dari intellect in habitu, kedua intellect in actu, dan terakhir adalah acquired intellect. Berdasarkan pernyataan tersebut, seorang anak yang bermula sebagai manusia terdidik untuk selanjutnya dapat menjadi guru bagi dirinya sendiri. Adapun bentuk realisasinya bersifat variatif, misalnya mereka telah memiliki kemampuan belajar dengan otodidak, atau mereka telah mampu dalam mengambil langkah dalam tindakannya tanpa terpengaruh dari perkataan orang lain.

Selanjutnya, Ikhwan Al Safa menyatakan bahwa ilmu merupakan sebuah pengetahuan yang dapat dipahami oleh mereka yang berilmu. Hakikat ilmu tidak dapat dipahami oleh manusia, kecuali mereka mencarinya melalui proses pembelajaran. Menurut Ikhwan Al Safa dalam kurun waktu empat tahun pertama bagi kehidupan seorang siswa untuk mendapatkan ilmu pengetahuan dicapai dengan tiga cara, yaitu pertama memanfaatkan pancaindera manusia dalam 


\section{AL- ADABIYAH: Jurnal Pendidikan Agama Islam}

memperoleh ilmu pengetahuan pada setiap zaman; kedua mengamati dan mendengarkan informasi dalam mempelajari hal yang abstrak, dan; ketiga melalui membaca dan menulis siswa dapat memahami makna dari suatu kalimat, bahasa, serta berbagai sudut pandang yang diperoleh dengan penalaran (Chanifah, 2020:51). Dalam memperoleh ilmu pengetahuan, perlu adanya sosok dalam memberikan arahan kepada siswanya, yaitu guru. Maka dari itu, diperlukan adanya pemahaman terkait ruang lingkup dalam pendidikan khususnya guru. Mengenai hal tersebut, Ikhwan Al Safa juga merancang beberapa hal yang berkaitan dengan pendidikan yang ditempuh oleh manusia.

Berkaitan dengan jalannya proses dalam kegiatan pengajaran, maka perlunya merencanakan tujuan pendidikan. Menurut Ikhwan Al Safa ilmu merupakan representasi pengatahuan dari setiap individu yang telah memiliki pengetahuan. Dalam Rasailnya pada juz 1 bahwa pembelajaran merupakan kegiatan dalam mengekspresikan pontensi menjadi aktual, maka tujuan utama pendidikan adalah moral (Izzati, 2016). Selanjutnya tentang fungsi pendidikan yaitu dapat membimbing siswa untuk mengimplementasikan upaya dalam pengembangan diri. Secara keseluruhan pendidikan merupakan aktivitas moral, yaitu meliputi pembentukan moral untuk menjadi baik, etiket manusia untuk lebih positif, perbuatan setiap manusia orientasinya bergerak secara lurus, memiliki keinginan untuk memberikan amanat kepada orang yang berhak, kecakapan dalam mengendalikan diri, bersikap baik antar-sesama, dan menjalankannya tanpa pamrih, sebab jika segala kebaikan moral memiliki niatan dengan maksud mendapatkan sanjungan atau balasan, maka hal tersebut tidak tergolong dalam nilai kebaikan, melainkan ke-nifaqan dan bagi orang tersebuk tidak sewajarnya berada pada barisan makhluk yang mulia (Sodik dan Zainol, 2018). Berdasarkan hal tersebut, alam pendidikan tujuan pendidikan Ikhwan Al Safa adalah untuk meningkatkan harkat manusia pada tingkatan yang lebih tinggi agar dapat meraih ridha Allah (Wathoni, 2018:297).

Dalam merealisasikan tujuan pendidikan, maka diperlukan beberapa ruang lingkup pendidikan dalam pendukung proses pembelajaran. Sebagai organisasi yang bergerak dalam bidang pemikiran pendidikan, Ikhwan Al Safa mengembangkan serangkaian sistematika pendidikan pada masanya yang dijelaskan dalam risalah. Dalam 52 risalah tersebut mengusahakan terbentuknya hubungan kurikulum dengan berbagai ilmu filsafat pada sekolah-sekolah Islam. Selain itu, mereka memberikan arahannya terhadap penemuan berbagai teori 


\section{AL- ADABIYAH: Jurnal Pendidikan Agama Islam}

dasar dalam pendidikan atau pengajaran, dan teori-teori tersebut memberikan kewajiban mendidik anak yang diawali dengan memanfaatkan pancaindera untuk mengamati sesuatu sebelum diolah melalui pemikiran rasional. Oleh karena itu, dalam mengamati suatu hal dengan pancaindera diperlukan adanya keterkaitan terhadap ilmu ketuhanan (teologi), sedangkan dalam merealisasikannya Ikhwan A1 Safa memberikan arahannya berupa metode dalam pengajaran. Menurut Afandi (2019) bahwa metode yang diperkenalkan oleh Ikhwan Al Safa berupa pemberian berbagai contoh yang sesuai dengan materi pelajaran yang diberikan. Alasanya adalah melalui metode tersebut, anak-anak atau siswa secara mudah dapat menangkap materi yang diberikan oleh guru.

\section{Pendidikan Islam Di Indonesia Pada Masa Pergerakan Nasional}

Sebelum memasuki abad ke-20, pendidikan Islam di Indonesia dapat dikatakan bersifat tradisional. Di sisi lain, kondisi pendidikan Islam pada masa itu cukup memprihatinkan, sehingga pada abad ke-20 memunculkan adanya gagasan untuk memberikan pembaruan dalam dunia pendidikan Islam. Hal tersebut dilatarbelakangi oleh beberapa faktor, yaitu faktor intern dan ekstern (Ramayulis 2012:295-297; Rahman, 2015). Adapun faktor internal terdiri atas, pertama adanya semangat kebangkitan dalam melawan kolonialisme Belanda; kedua rasa kecewa terhadap kebijakan kolonial Belanda dalam pendidikan; ketiga tidak puas dengan pengetahuan dalam Islam ketika itu dan praktik adat ditengah kehidupan masyarakat, dan; keempat hasrat golongan muda untuk mengembalikan kemurnian ajaran Islam. Selanjutnya, faktor ekstern yaitu adanya pengaruh oleh pemikiran dari berbagai tokoh pembaruan di kawasan Timur Tengah pada abad ke19 Masehi, khususnya Jamaludin Al-Afghani dan Muhammad Abduh. Gerakan yang dipelopori oleh mereka secara eksplisit menentang penjajahan yang dilakukan oleh dunia barat terhadap negara Islam. Berdasarkan hal tersebut, mendorong Jamaludin Al-Afghani berserta Muhammad Abduh untuk mengajak umat Islam untuk mengekplorasi berbagai kajian ilmu pengetahuan layaknya seperti sebagian negara di dunia barat pada masa Renaissance dan Aufklarung. Maka dari itu, langkah yang dilakukan oleh beberapa tokoh pembaruan dalam dunia Islam menyerukan kepada penataan kehidupan diberbagai bidang, termasuk pendidikan.

Gerakan pembaruan terhadap pendidikan Islam di Indonesia pada abad ke-20 Masehi lazimnya disebut sebagai langkah modernisasi dalam pendidikan Islam. Hal tersebut diawali dengan kritikan terhadap sistem pendidikan Islam yang cenderung masih bersifat tradisional (Subhan, 2012:105). Pasca tibanya para pelajar dari 


\section{AL- ADABIYAH: Jurnal Pendidikan Agama Islam}

Indonesia yang menimba ilmu di Mesir dan bersamaan dengan penerapan pendidikan dari bagian Politik Etis Belanda, mereka memiliki semangat kemajuan atas Indonesia. Semangat yang dimiliki oleh para pelopor modernisasi pendidikan Islam yaitu dengan cara menggabungkan sistem pendidikan modern yaitu yang telah oleh kolonial Belanda dengan pengalaman mereka saat berada di Mesir. Adapun bentuk implementasinya yaitu dengan berdirinya sekolah Islam yang dikenal dengan madrasah di beberapa wilayah Indonesia. Awal berdirinya lembaga pendidikan Islam bercorak modern pertama di Indonesia yaitu berdiri pada tahun 1907 dengan nama Adabiyah School oleh Abdullah Ahmad di Minangkabau. Sekolah tersebut mengintegrasikan pola pendidikan umum seperti yang diterapkan oleh pemerintah kolonial Belanda dan diwarnai oleh sistem pendidikan Islam. Adapun tujuan atau harapan yang ingin dicapai oleh Adabiyah School adalah agar dapat menjadi sekolah seperti gubernemen Islam dan diorientasikan terhadap tranformasi watak bagi setiap individu dengan misi melepaskan umat dari taklid (Al Farabi, 2020). Berdirinya Adabiyah School dapat dikatakan sebagai perintis pendidikan modern di Indonesia yang kemudian diikuti dengan berdirinya beberapa lembaga pendidikan Islam serupa, seperti Muhammadiyah, Nahdlatul Ulama, PERSIS, dan sebagainya.

Muhammadiyah sebagai salah satu organisasi yang bergerak di bidang pendidikan Islam berdiri pada tanggal 8 Dzulhidjah 1330 Hijriah (10 November 1912) oleh KH. Ahmad Dahlan di Yogyakarta. Tujuan dari pendirian Muhammadiyah yaitu membebaskan umat Islam dari segala bentuk kekakuan dalam berbagai bidang kehidupan dan penerapan ajaran agama yang dinilai telah tidak sesuai dengan ajaran agama Islam yang murni (Sabarudin, 2015). Selain itu, dijelaskan pula oleh Rahem (2017) bahwa alasan KH. Ahmad Dahlan menyerukan untuk kembali ke ajaran Islam yang murni, karena kondisi masyarakat di Yogyakarta ketika itu diwarnai dengan pengaruh tahayuul, bid'ah, dan khufarat yang dapat menjerumus manusia pada syirik. Selanjutnya, Ahmad Dahlan mendobrak sistem pesantren, dimana menurutnya pesantren merupakan lembaga pendidikan Islam yang masih bersifat tradisional, sehingga diperlukan adanya pembenahan dalam sistem pesantren yang hendaknya dapat sejajar dengan gerakan para kolonial Belanda untuk memajukan dunia pendidikan. Ahmad Dahlan selaku pendiri Muhammadiyah, menyatakan bahwa kondisi masyarakat Indonesia dibawah kekuasaan kolonialisme Belanda menyebabkan kemunduran pada berbagai bidang, baik ekonomi, sosial dan politik karena pemerintah ketika 


\section{AL- ADABIYAH: Jurnal Pendidikan Agama Islam}

itu adanya pembatasan kepada masyarakat untuk terjun dalam sektor pemerintahan dan berbagai perusahaan swasta. Maka dari serangkaian kondisi yang telah dijelaskan medorong Ahmad Dahlan untuk menyusun sebuah tujuan pendidikan Islam yaitu untuk berupaya membentuk manusia agar memiliki budi yang luhur, patuh terhadap agama, memiliki pemahaman secara menyeluruh dan menginterpretasikan suatu problematika pada ilmu keduniawian, serta berkenan untuk memperjuangkan kemajuan masyarakat (Ni'mah 2014). Dalam mencapai tujuan tersebut maka pendidikan Islam perlu melakukan akomodasi dengan berbagai jenis ilmu pengetahuan, baik agama maupun umum, sehingga mampu meningkatkan aspek intelektual dan spiritual bagi siswa.

Organisasi selanjutnya yaitu Nahdlatul Ulama (NU), yang didirikan oleh KH. Hasyim Asy'ari dan KH Wahab Chasbullah di Surabaya pada tanggal 13 Januari 1926. Respon KH, Hasyim Asy'ari terhadap dunia pendidikan ketika itu karena dianggap telah menjadi hal yang lazim akibat pengaruh dari sistem pendidikan kolonialisme modern Belanda yang bercorak modern. Berdasarkan hal tersebut maka pendidikan dijelasknya secara aktual dan dirincikan dalam ruang lingkup pendidikan. Adapun tujuan pendidikan yang digalakkan oleh KH. Hasyim Asy'ari menurut T. Burhannudin dalam (Zein, 2010:41) yaitu pertama menitikberatkan dalam upaya menggapai derajat ulama dan insan; kedua dapat memberikan amalan baik dari ilmu yang telah diperoleh, dan; ketiga dapat meraih ridho Allah. Selanjutnya, mengenai basis gerakan Nahdlatul Ulama dalam pendidikan tradisional tidak memungkinkan untuk dipertahankan dimasa yang akan datang, maka diperlukan adanya pembaruan yang dilakukan secara bertahap dan tetap menjaga keberlanjutan tardisi. Berdasarkan hal tersebut, Nahdlatul Ulama melalui ma'arifnya memulai usaha pembaruan dalam pendidikan Islam sekitar tahun 1930-an. Dalam pendidikan yang digagaskan oleh Nahdlatul Ulama cenderung pada konsep manusia dinamis, yaitu manusia yang bersikap rasional, tanggungjawab, selalu berpendapat mampu bergerak kearah yang lebih baik menuju pada tingkat yang lebih sempurna (kamil) (Najib, 2020).

Adapun dampak dari pembaruan pendidikan Islam pada masa pergerakan memberikan perubahan dalam berbagai ranah pendidikan Islam, yaitu mencakup sistem, lembaga, administrasi, pelaksanaan pendidikan Islam, maupun lulusan pada instusi pendidikan tersebut. Berdasarkan hal tersebut memberikan indikasi bahwa pembaruan sistem pendidikan Islam yang menuju pada modernisasi 


\section{AL- ADABIYAH: Jurnal Pendidikan Agama Islam}

menyiratkan pembaruan tersebut sebagai respon terhadap berbagai sekolah pemerintah Belanda yang netral terhadap agama (Hasnida, 2017).

\section{Perbandingan Tujuan Pendidikan Ikhwan Al Safa Dengan Pendidikan Islam Di Indonesia Masa Pergerkan}

Berdasarkan paparan diatas, bahwa gerakan dalam bidang pendidikan khususnya Islam antara pada tahun 983 Masehi di daerah Basrah oleh Ikhwan Al Safa dengan pendidikan islam pada abad ke-20 (masa pergerakan nasional) memiliki persamaan. Mengenai hal tersebut yaitu, pemikiran terhadap kondisi pendidikan di dua wilayah yang berbeda dimotori oleh sebuah organisasi yang bergerak dalam agama Islam. Namun, hal yang membedakannya adalah Ikhwan Al Safa bergerak secara rahasia, hal ini dikarenakan adanya rasa khawatir terhadap penguasa pada masa itu yang cenderung memberikan penindasan terhadap munculnya paham baru, dan diperikiran karena adanya pengaruh dari paham taqiyah. Kerahasiaan organisasi tersebut memberikan informasi bahwa mengenai keberadaannya menjadi hal yang tabu. Namun, untuk menyebarkan paham dan ajarannya mereka mengirim seseorang ke beberapa wilayah. Berbeda halnya dengan organisasi Islam yang berada di Indonesia yang bergerak secara terbuka walaupun dibawah kekuasaan kolonialisme Belanda dan dilakukan secara sempit, hal ini dikarenakan adanya rasa nasionalisme dalam diri tokoh pelopor dari organisasi Islam yang bersangkutan untuk memperadabkan masyarakat pribumi, khususnya bagi mereka yang tidak mengenyam pendidikan. Terkait hal tersebut, pemerintah kolonial Belanda memberikan pembatasan terhadap pendirian organisasi dan memperkenankan setiap organisasi tersebut untuk meminta izin terhadap pemerintah kolonial Belanda. Walaupun pemberian izin diberikan, tetapi tidak sepenuhnya organiasi Islam tersebut dapat bergerak bebas dan tetap berada dibawah pengawasan pihak kolonial Belanda.

Terkait tujuan pendidikan, khususnya berbasis pada agama Islam antara Ikhwan Al-Safa dengan organisasi Islam yang bergerak dalam bidang pendidikan pada masa pergerakan nasional memiliki persamaan yaitu untuk mencetak generasi yang berlandaskan pada ajaran pada agama Islam. Selain itu, tujuan lainnya adalah menciptakan manusia dengan konsep insan kamil. Adapun maksudnya dijelaskan dalam Sodik dan Zainol (2018) bahwa manusia yang dimaksudkan dalam insan kamil adalah secara keseluruhan manusia secara utuh terpenuhi pada aspek rohani dan jasmaniah untuk melangsungkan kehidupan dan berkembang secara lumrah atas dasar ketakwaannya terhadap Allah. 


\section{AL- ADABIYAH: Jurnal Pendidikan Agama Islam}

Ikhwan Al Safa yang menunjukkan tujuan pendidikannya kepada pembentukan moral, bersifat sosial, dan intelektual, sehingga mereka mengemasnya terhadap teori yang dikemukakannya dengan konteks moral yaitu kewajiban manusia dalam menguasai ilmu pengetahuan yang bertujuan untuk meningkatkan kualitas dan rasa mulianya, sehingga pada akhirnya dapat dijadikan sebagai tanggung jawab setiap manusia pada dirinya sendiri, antarsesama, dan Tuhannya. Terkait hal tersebut, Ikhwan Al Safa dikatakan menganut aliran yang bersifat religius-rasional. Berdasarkan pandangan religius-rasional dalam epistemologi dilandaskan pada kekuatan religius, pendidikan Islam didorong atas dasar kesadaran spiritual dari Tuhan berupa wahyu, sedangkan rasional dijadikan sebagai aspek pembangun kesadaran ilmiah untuk membangun pendidikan Islam (Kurniawan, 2019).

Pada masa pergerakan nasional berbagai organisasi Islam yang tumbuh dan berkembang di Indonesia memiliki karakteristik tersendiri dalam merencanakan tujuan pada bidang pendidikan yang didasarkan pada agama Islam. Berdasarkan hal tersebut, pada penulisan jurnal ini mengambil dua organisasi besar yang berkontribusi pada perkembangan pendidikan pada masa itu, yaitu Muhammadiyah dan Nahdlatul Ulama. Setelah menemukan ide pembaruan modern dalam dunia pendidikan Islam, adapun perbedaan keduanya dalam tujuan pendidikan berdasarkan filsafat yaitu, jika Muhammadiyah lebih mengarah pada aliran progresivisme-rekonstruksi sosial, sedangkan Nahdlatul Ulama essensialisme-perennialisme. Adapun definisi dari aliran progresivisme yaitu aliran yang mengarahkan siswa untuk berorientasi kepada hal yang positif dalam perubahannya. Selain itu, dalam aliran progresisvisme pendidikan tidak hanya berpacu pada pembaruan terhadap pengetahuan kepada siswa, melainkan melalui pendidikan diharapkan siswa dapat mengasosiasikan suatu fakta kehidupan yang akan terjadi di masa yang akan datang (Ruslan, 2018). Adanya penambahan rekonstruksi sosial, karena kondi masyarakat pada masa itu tidak berlandaskan pada kemurnian ajaran agama Islam, sehingga melalui pendidikan dan mengikuti proses pembelajannya, diharapkan umat manusia dapat kembali pada ajaran yang benar. Selanjutnya mengenai aliran essensialisme-perennialisme didefinikasikan sebagai gabungan dari dua aliran filsafat yaitu pertama essensialisme yang menghendaki pendidikan mengacu pada nilai jelas dan tahan lama, sedangan perennialisme merupakan aliran yang menghendaki adanya gerakan kembali pada kebudayaan masa lalu yang dianggap ideal (Isna dkk, 2017). Berdasarkan hal 


\section{AL- ADABIYAH: Jurnal Pendidikan Agama Islam}

tersebut, Nahdlatul Ulama menerapkannya pada bidang pendidikan dengan menjaga tradisi yang telah ada, dan dimasa yang akan datang serta menjadi manusia yang dinamis.

\section{Kesimpulan}

Ikhwan Al Safa merupakan organisasi rahasia yang bergerak dalam pendidikan, khususnya dalam agama Islam dan berpusat di kota Basrah. Latar belakang pendirian organisasi tersebut disebabkan oleh kondisi penyelenggraan pendidikan Islam yang sangat memprihatikan dan masuknya pengaruh ajaran dari luar Islam, sehingga mendorong semangat mereka untuk menggalakkan rasa cinta terhadap ilmu pengetahuan. Begitupun pada masa pergerakan nasional di Indonesia, dimana kondisi masyarakat ketika itu jauh terbelakang karena dampak dari pengaruh kolonialisme Belanda. Gerakan pendidikan yang diprakarsai oleh Ikhwan Al Safa dan berbagai organisasi Islam di Indonesia memiliki persamaan dalam tujuannya yaitu agar manusia secara keseluruhan dapat memenuhi aspek dalam rohani dan jasmaniah untuk melangsungkan kehidupan dan berkembang secara lumrah atas dasar ketakwaannya terhadap Allah. Namun, diantara keduanya memiliki perbedaan dalam pandangan yang dianut dan pemikirannya dalam pendidikan Islam. Mengingat organisasi Islam di Indonesia tersebar diberbagai daerah pada masa pergerakan nasional, maka antara pemikiran satu organisasi dengan yang lainnya berbeda. Dalam hal ini mengambil dua contoh organisasi Islam yaitu Muhammadiyah dan Nahdlatul Ulama. Muhammadiyah menganut aliran progesivisme-rekonstruksi sosial, sedangkan Nahdlatul Ulama menganut essensialiseme-perennialisme. Adapun Ikhwan Al Safa sebagai organisasi Islam yang bergerak dalam bidang pendidikan Islam menganut aliran religius-rasional yaitu pendidikan tidak hanya berpacu pada sesuatu yang kajiannya bersifat rasional-empirik, melainkan proses pendidikan juga menghadirkan segala hal yang bersifat transedental.

\section{Referensi}

Afandi, R. (2019). Konsep Pendidikan Ikhwan Al-Shafa dan Relevansinya dengan Dunia Postmodern. INSANIA: Jurnal Pemikiran Alternatif Kependidikan, 24(1), 150-166.

Al Farabi, M. 2020. Modernisasi Pendidikan Islam di Indonesia: Kasus Adabiyah School. Islamijah: Journal of Islamic Social Sciences, 1(3), 248-271.

Chanifah, N. (2020). Model Pembelajaran Pendidikan Agama Islam Berbasis Direct Experience-Mulitidiciplinary. Banyu Mas: Pena Persada. 
Hanipudin, S. (2019). Pendidikan Islam di Indonesia dari Masa ke Masa. Matan: Journal of Islam and Muslim Society, 1(1), 39-53.

Hasnida, H. (2017). Sejarah Perkembangan Pendidikan Islam di Indonesia pada Masa PRA Kolonialisme dan Masa Kolonialisme (Belanda, Jepang, Sekutu). Kordinat. Jurnal Komunikasi Antar Perguruan Tinggi Agama Islam, 16(2), 237256.

Hidayatullah, F. S. (2013). Relevansi Pemikiran Ikhwan al-Shafa Bagi Pengembangan Dunia Pendidikan. Ta'dib: Journal of Islamic Education (Jurnal Pendidikan Islam), 18(01), 43-55.

Ibda, H. (2018). Filsafat Umum Zaman Now. Pati: Kataba Group.

Isna, I., dkk. (2017). Pendidikan Karakter menurut Aliran Essensialisme, Parennialisme, Progresivisme, dan Eksistensialisme. Retrieved from http://eprints.umsida.ac.id/617/.

Izzati, H. (2016). Pemikiran Pendidikan Ikhwan Al-Shafa. Jurnal Al-Mutaaliyah: Jurnal Pendidikan Guru Madrasah Ibtidaiyah, 1(1), 99-110.

Kristiawan, M. (2016). Filsafat Pendidikan: The Choice Is Yours. Yogyakarta: Valia Pustaka Yogyakarta.

Kurniawan, F. (2019). Pengembangan Teori Pendidikan Islam Perspektif Muhammad Jawwad Ridla (Religius Konservatif, Religius Rasional, Pragmatis Instrumental). At-Ta'lim: Media Informasi Pendidikan Islam, 18(1), 223-242.

Najib, A. A. (2020). Konsep Dasar Pendidikan Nahdlatul Ulama KH. Hasyim Asy'ari. Al Ulya: Jurnal Pendidikan Islam, 5(1), 67-80.

Nasution, A. T. (2016). Filsafat Ilmu Hakikat Mencari Pengetahuan. Yogyakarata: Deepublish.

Ni'mah, Z. A. (2014). Pemikiran Pendidikan Islam Perspektif KH. Ahmad Dahlan (1869-1923 M) dan KH. Hasyim Asy'ari (1871-1947 M): Study Komparatif dalam Konsep Pembaruan Pendidikan Islam di Indonesia. Didaktika Religia, 2(1), 135-174.

Nursyarief, A. (2014). Pendidikan Islam di Indonesia dalam Lintasan Sejarah (Perspektif Kerajaan Islam). Lentera Pendidikan: Jurnal Ilmu Tarbiyah dan Keguruan, 17(2), 256-271.

Rahman, R. (2015). Modernisasi Pendidikan Islam Awal Abad 20 (Studi Kasus di Sumatera Barat). Humanus, 14(2), 174-182.

Rajab, L. (2016). Konsep Pendidikan Islam Ikhwan As-Shafa (Suatu Kajian analisis Kritis). al-Iltizam: Jurnal Pendidikan Agama Islam, 2(1), 64-77.

Ritaudin, M. S. (2015). Mengenal Filsafat dan Karakteristiknya. Kalam, 9(1), 127144.

Ruslan, R. (2018). Perspektif Aliran Filsafat Progresivisme Tentang Perkembangan Peserta Didik. JISIP (Jurnal Ilmu Sosial dan Pendidikan), 2(2), 211-217.

Sabarudin, M. (2015). Pola dan Kebijakan Pendidikan Islam Masa Awal dan Sebelum Kemerdekaan. TARBIYA: Jurnal Ilmu Pendidikan Islam, 1(1), 139-174. 
Sagala, S. (2013). Etika \& Moralitas Pendidikan: Peluang dan Tantangan. Jakarta: Prenada Media.

Sodik, H., \& Moh. Zainol Kamal.( 2018). Konsep Pendidikan Islam Menurut Ikhwān Al-Shafā. Jurnal Pusaka, 6(1), 92-104.

Soeprapto, S. (2013). Landasan aksiologis sistem pendidikan nasional Indonesia dalam perspektif filsafat pendidikan. Cakrawala Pendidikan, 32(2), 266-276.

Subhan, A. (2012). Lembaga Pendidikan Islam Indonesia Abad Ke-20: Pergumulan Antara Modernisasi dan Identitas. Jakarta: Kencana.

Tim Riset Majelis Tinggi Urusan Islam Mesir. 2015. Silsilah Al-Mawsu'at AlIslamiyah Al-Mutakhashshishah (Masturi Irham dkk Trans.). Jakarta: Pustaka Al-Kautsar.

Wathoni, L. N. M. (2018). Filsafat Pendidikan Islam: Analisis Pemikiran Filosofis Kurikulum 2013. Ponorogo: Uwais Inspirasi Indonesia.

Zein, R. (2010). Sistem Pendidikan Islam di Indonesia Pada Awal Abad XX (1900-1945); Studi Komparatif Pembaruan Sistem Pendidikan KH. Hasyim Asy ari dan KH. Ahmad Dahlan. Retrieved from http://repository.uin-suska.ac.id/1490/1/2011_201143.pdf. 